فاعلية برناهج تعليمي بالحاسوب لتنسية المعارف والمهارات الأساسية لفن الكروشيه لطالبات الاقتصاد المنزلي ع كلية التربية جاهعة نجران

إعلاد

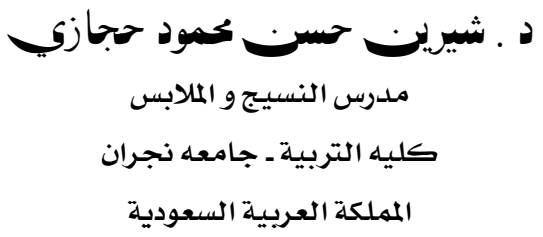

مجلة بحوث التربية النوعية ـ جامعة المنصورة

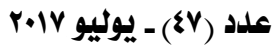


فاعلية برنامج تعليهي بالحاسوب لتنمية المعارف والمهارات الأساسية لفن الكروثيه لطالبات الاقتصاد المنزلي بـ 
مجلة بحوث التربية النوعية - علدد VI - بوليو r.lV

فاعلية برناهج تمليمي بالهاسوب لتنمية المعارف والمهارات الأساسية لفن الكروشيه لطالبات الاقتصاد المنرلي س كلية التربية جاهمة نهران

إعداد

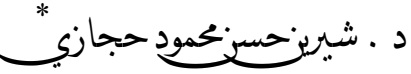

unil|

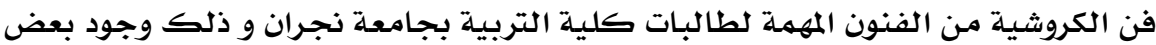

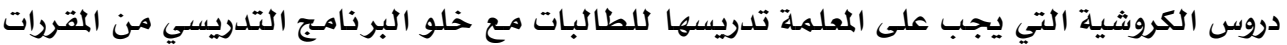

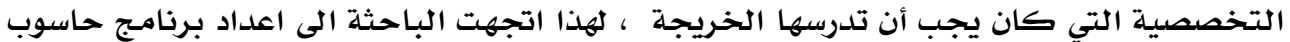

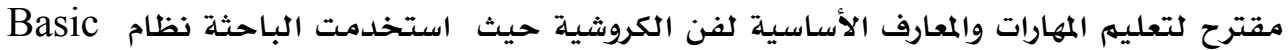

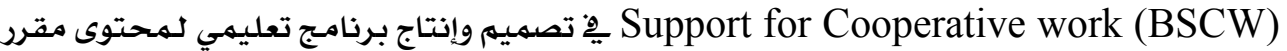

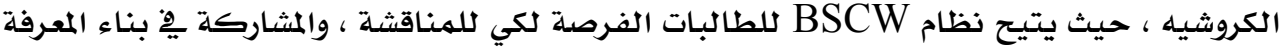

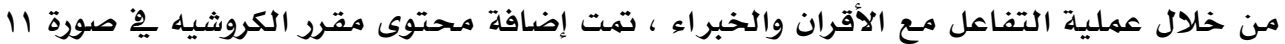

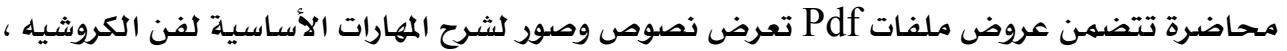

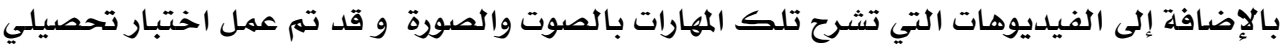

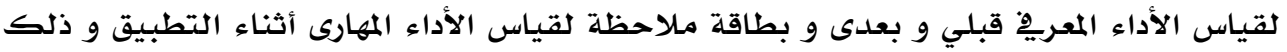

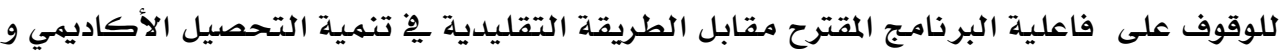

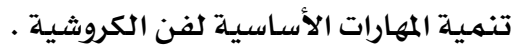

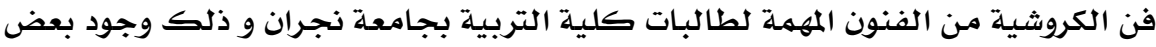

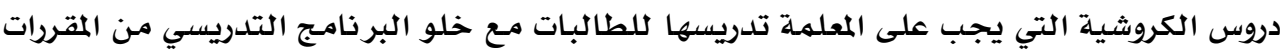

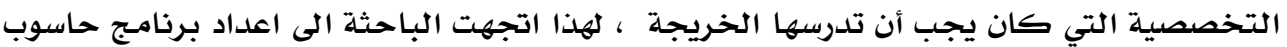

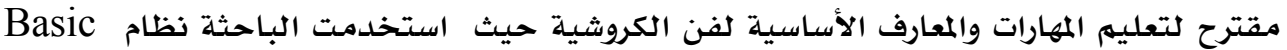
Support for Cooperative work (BSCW) الكروشيه ، حيث يتيح نظام BSCW للطالبات الفرصة لكي للمناقشة ، والمثاركة ِيْ بناء المعرفة

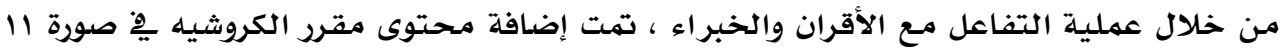

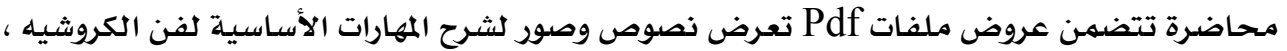

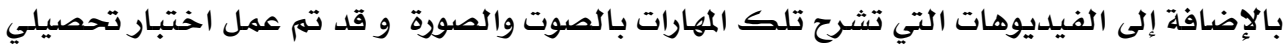

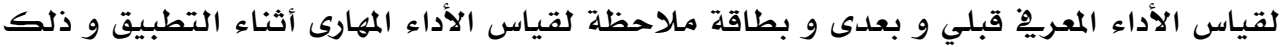


للوقوف على فاعلية البرنامج المقترح مقابل الطريقة التقليدية يْ تتمية التحصيل الأكاديهي و

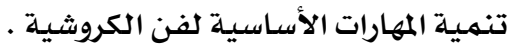

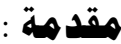

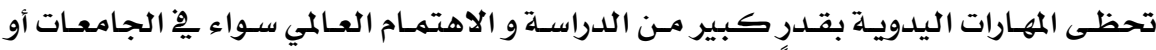

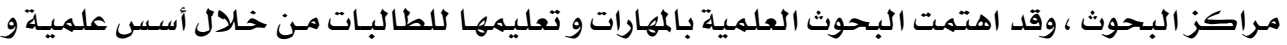

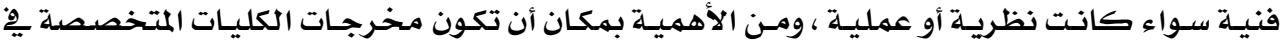

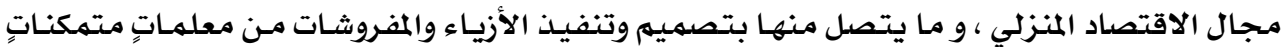

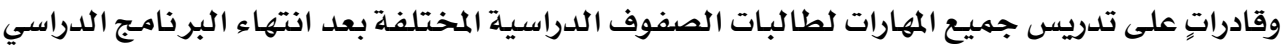

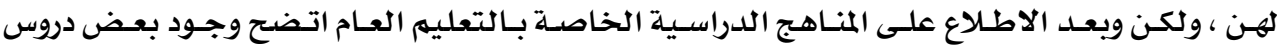

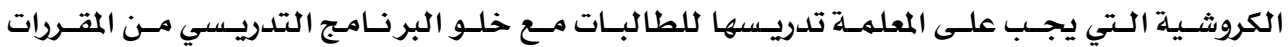

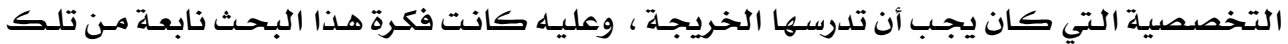

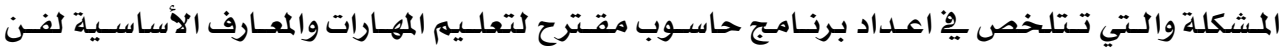

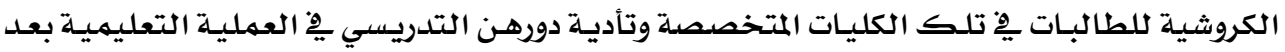

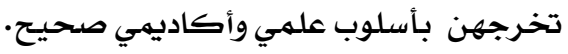

$$
\text { يهدف البحث الى : بالى }
$$

1 ـ تحديد المهارات الأساسية لفن الكروشية المطلوب أن تكتسبها الطالبات .

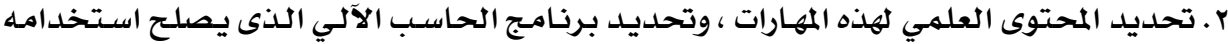

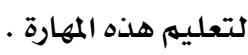

ץ. تحديد مـدى فاعليـة البر نامـج المقترح مقارنـةً بـالطريقـة التقليديـة لتدريس المهارات الأسـاسية

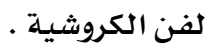

\section{تسماؤلات البمث:}

ا.ما هي أسس ومكونات البر نامـج المقترح لتعليم المهارات الأساسية لفن الكروشية؟

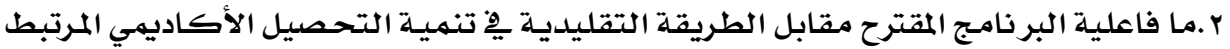

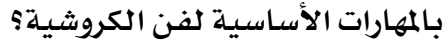

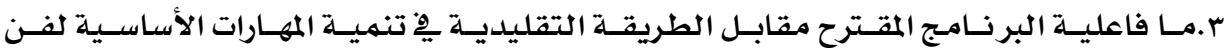

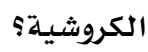

\section{فروض الدراسة :}

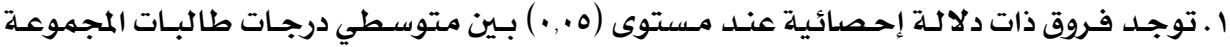

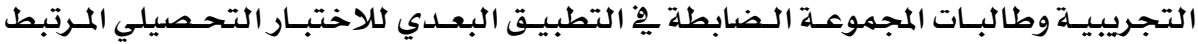

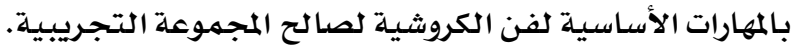


ب مجلة بحوث التربية النوعية - علدد

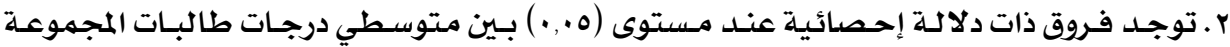

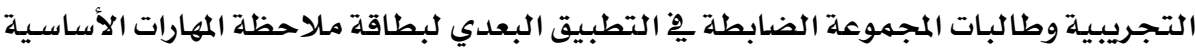

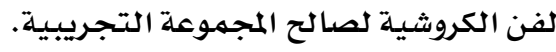

\section{أهمية الدراسة :}

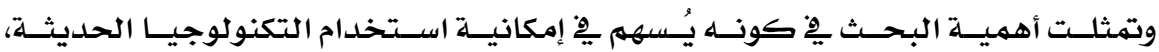

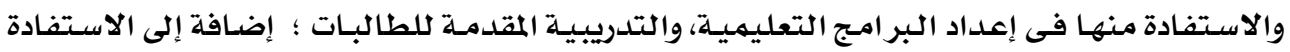

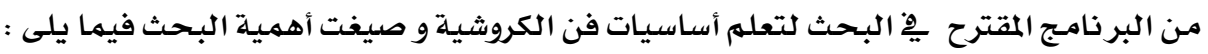

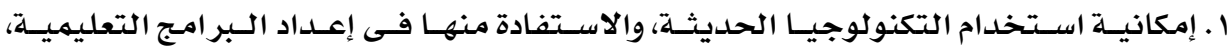

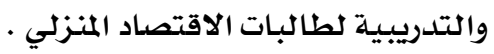

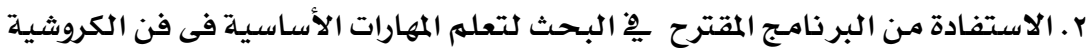

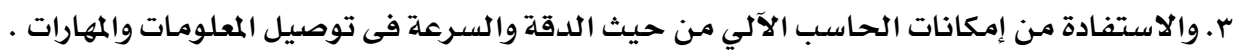

\section{حدود الدراسية:}

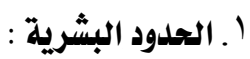

يتم تطبيق البحث على طالبات قسم الاقتصاد المنزبي كلية التربية جامعة نجران .

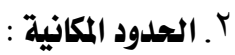

يتم تطبيق إجراءات الدراسـة كاملة بجامعة نجران كلية التربية قسم الاقتصاد المنزلي بالمملكة العربية السعودية

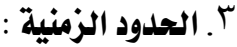

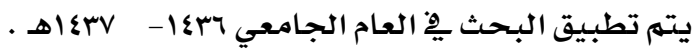

\section{أدوات الدراسة:}

$$
\begin{aligned}
& \text { 1- اختبار تحصيلي لقياس الأداء المعربِّ قبلي و بعدى . }
\end{aligned}
$$

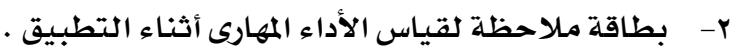

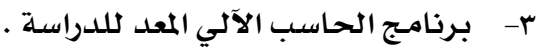

$$
\begin{aligned}
& \text { ع- الأسلوب الإحصائي. } \\
& \text { همطاتحات البمث: }
\end{aligned}
$$

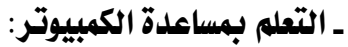

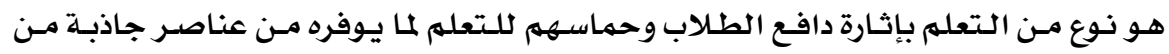

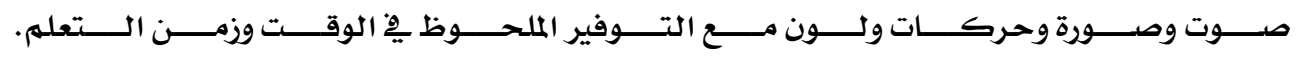

( كريمـة عبد العزيز لبن 7 ( 
هـو حياكـة أو لـف الخـيط بـالإبر الصغيرة وهـي عبـارة عن إبـرة خاصسة لهـا شـكل معكـوف

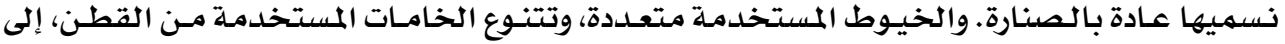

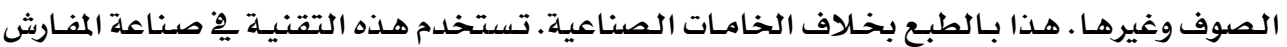

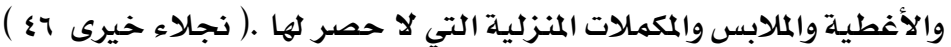

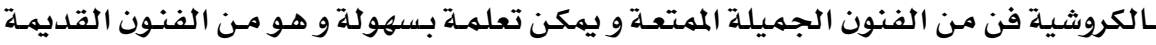

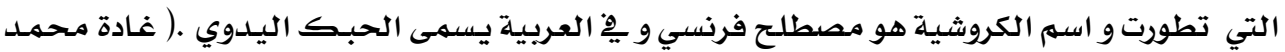

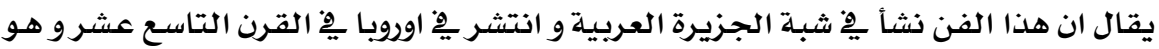

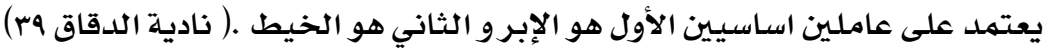

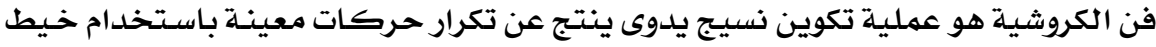

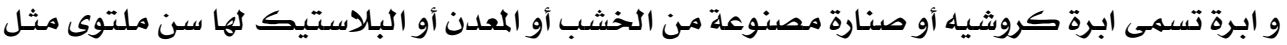

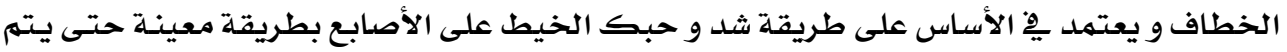
(ar.wikipedia.org ). تماسك النسيج

هـو حياكـة أو لـف الخـيط بـالإبر الصغيرة وهـي عبـارة عن إبـرة خاصسة لهـا شـكل معكـوف

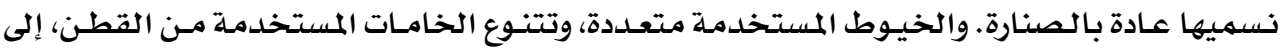

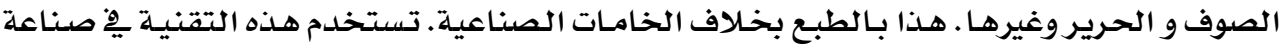

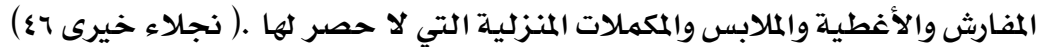
ولقد اختارت الباحثة تعلمم أساسيات فن الكروشيلة لطالبـات الاقتصاد المنزلي وذلك لأن

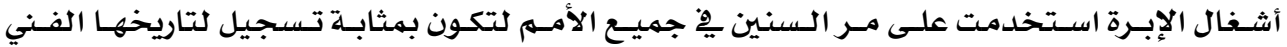

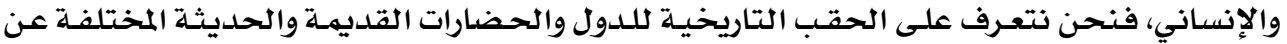

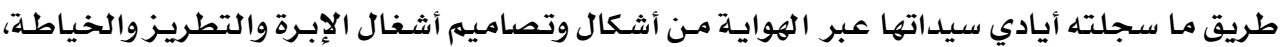

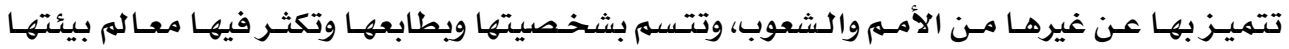

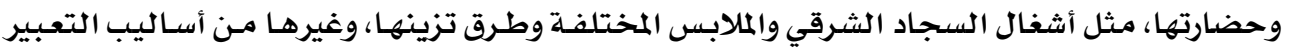

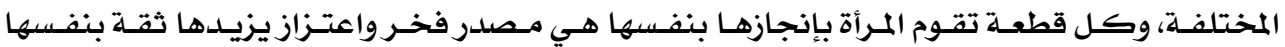

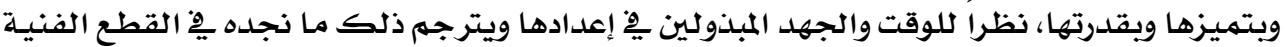

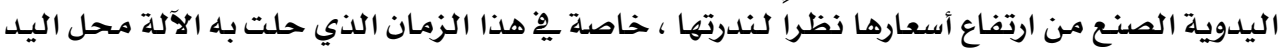

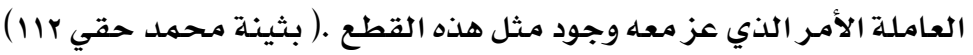

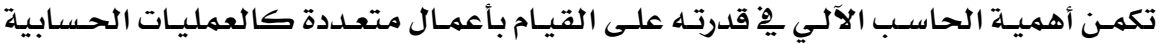

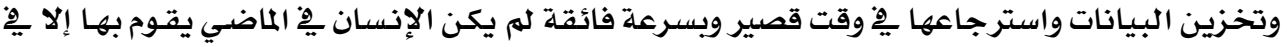

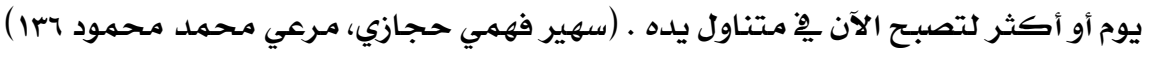
وعلى الرغم من ظهور أسـاليب تكنولوجيـة حديثة يِّ مجـال الملابس والنسيج إلا أنه مـا زال

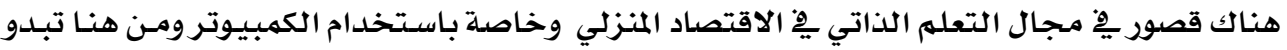




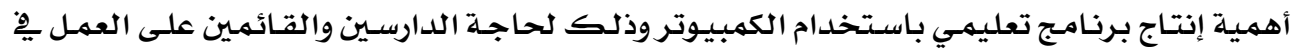

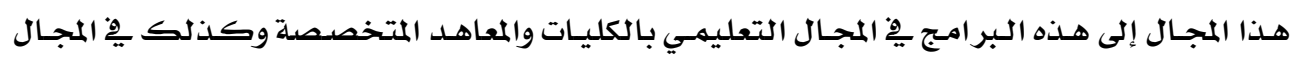

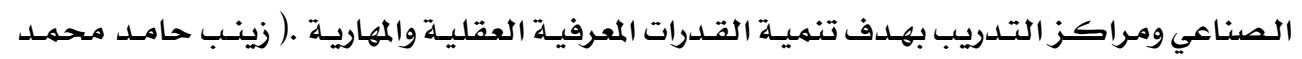

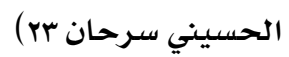

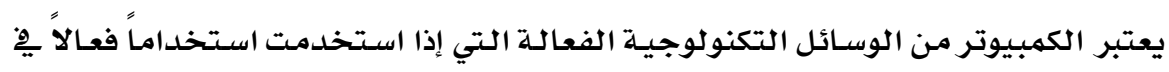

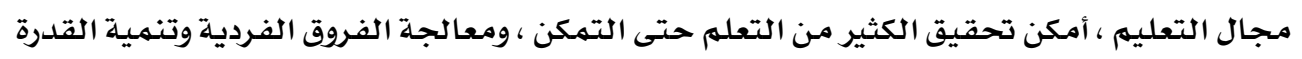

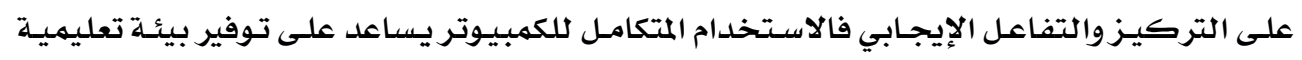

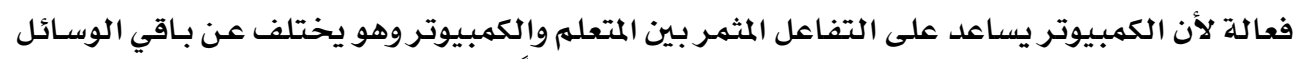

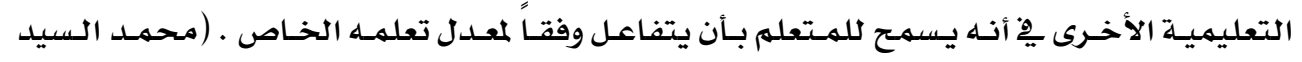

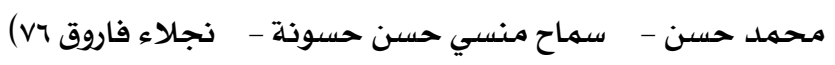

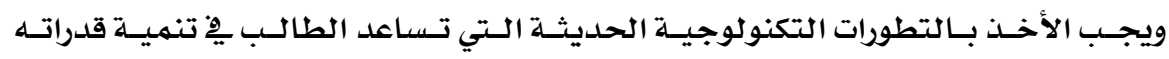

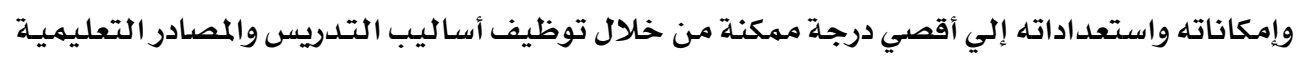

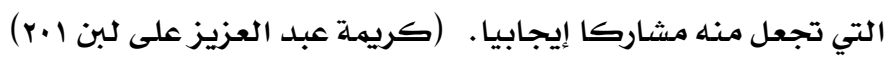

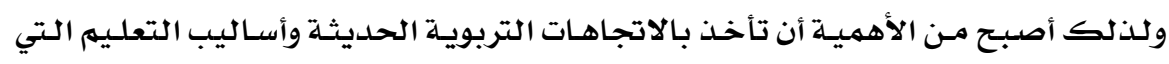

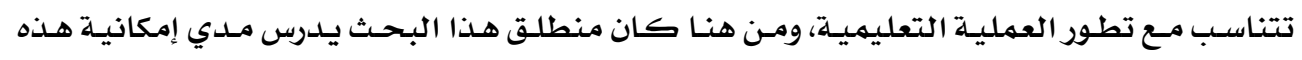

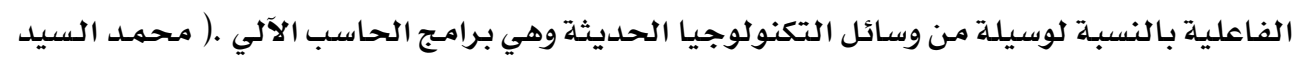

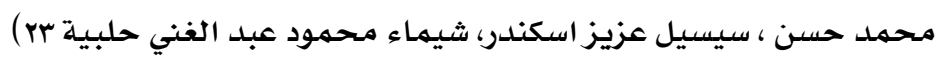

\section{الدراسات السابقة :}

ا- دراسة كريمة عبــ العزيز على لـبن ( إمكانيـة الاستفادة مـن نظم تكنولوجيـا الحاسب الآلكي

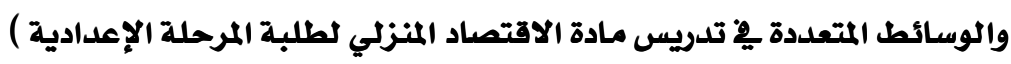

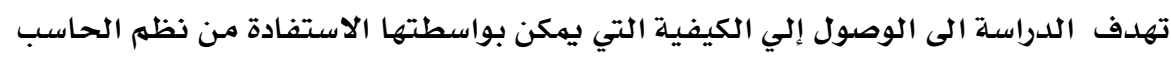

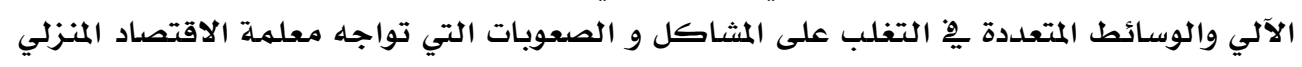

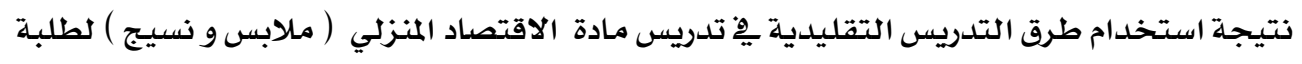

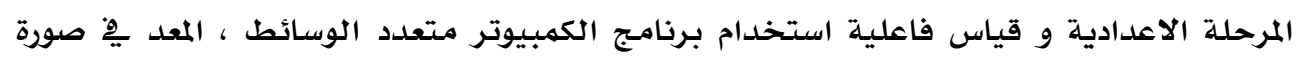

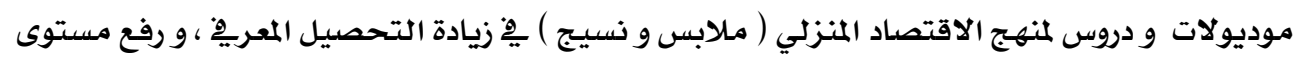

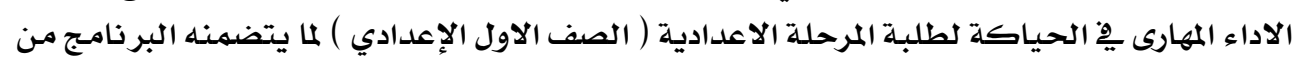

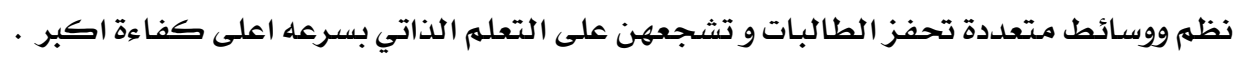
وتوصلت الدراسة الى وجود فروق ذات دلالة احصائية بين متوسط درجات تلميذات -

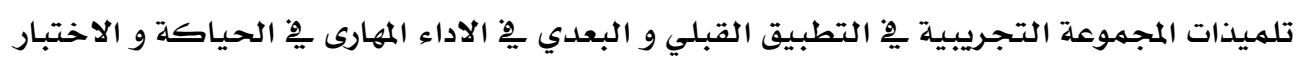

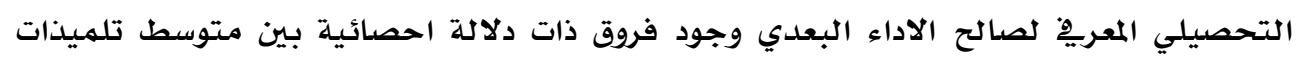




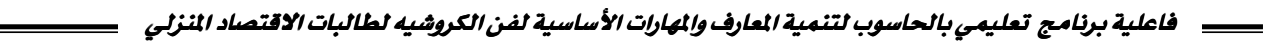
المجوعتين التجريبية و الضابطة ِِّ التطبيق البعدي لاختبار التحصيل المعربِ - لصالح الاداء البعدي للمجموعة التجريبية .

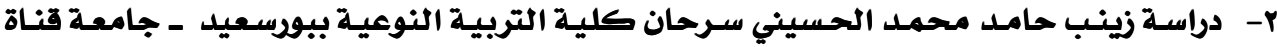

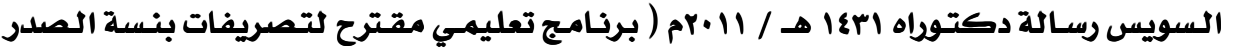

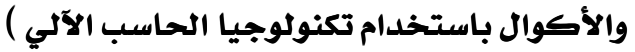

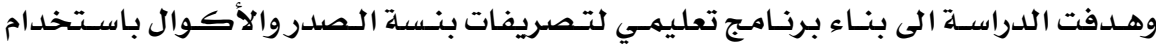

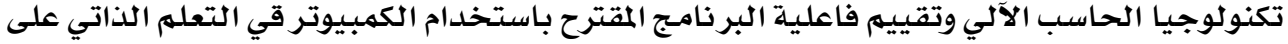

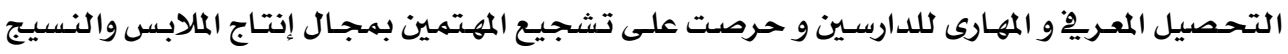

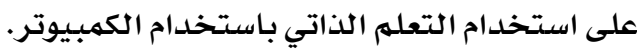

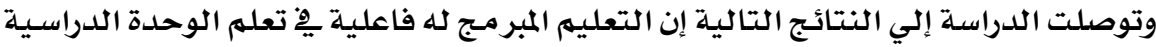

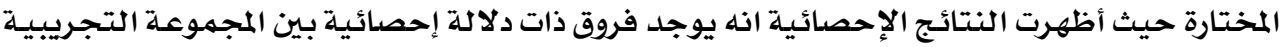

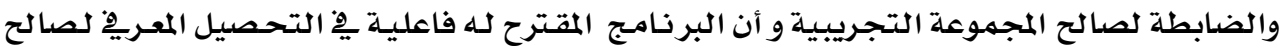

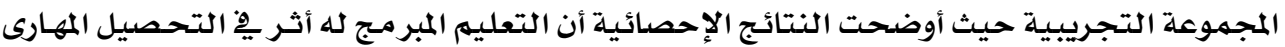

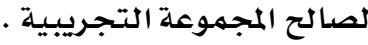

r- دراسة محمد السيد محمد حسن- سماح منسي حسن حسونة - نجلاء فاروق كلية التربية

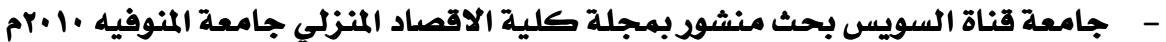
بعنوان (فاعلية برامج الكمبيوتر متعـددة الوسـائط يْ مـاد ة تصميم الأزياء للدي طالبـات قسم الاقتصاد المنزلي بكلية التربية" (فاعلية برامية )

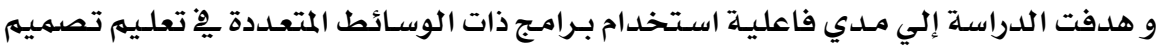
الأزياء لدي طالبات الفرقة الثانية قسم الاقتصاد المنزلي بكلية التربية ومقارنته بالطريقة المعتادة. وتم التوصل إلي انه لا توجد فروق دالـة بـين متوسطات رتب المجموعـة الضابطة والمجموعـة

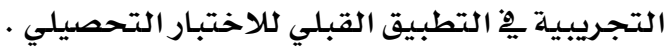

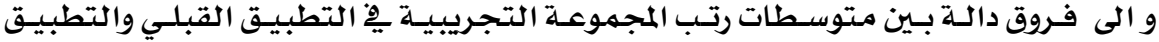

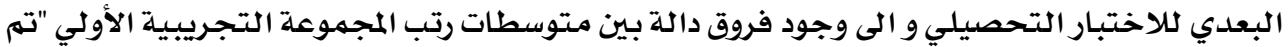

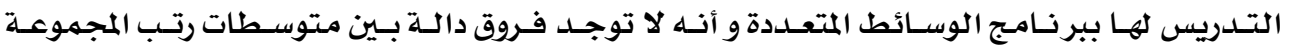

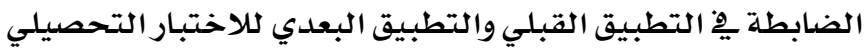
إجراءات البحث : أولاً: منهج البحث:

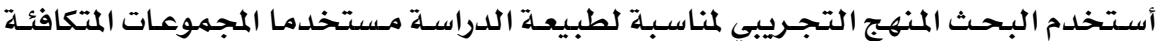

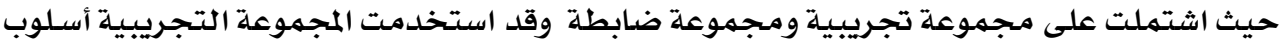

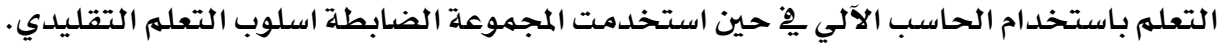




\section{ثانياً: عينه البحث:}

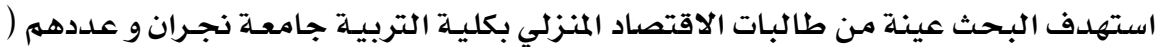

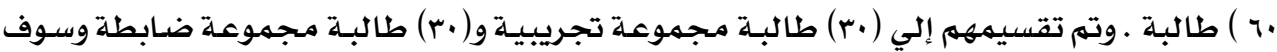

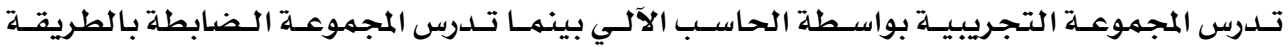

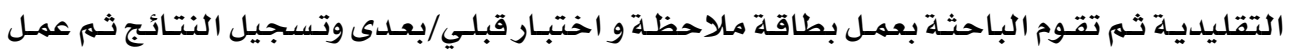

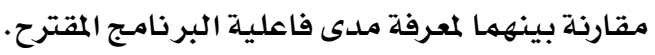
وقد تم اختيار افراد العينة حيث : - أن جميع افراد العينة مبتدئات مِّْ تعلم فن الكروشية. - أن جميع افراد العينة يتلقون خطة دراسية واحدة مهاريا ونظريا . وسار البحث وفقاً للخطوات التالية: - تحديد محتوى البرنامـج التعليمى المستخدم لتعلم المهارات الأساسية لفن الكروشيه .

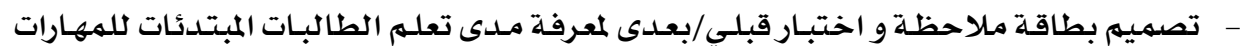

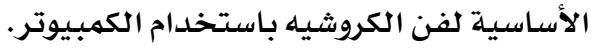
- - تحكيم الاختبار من قبل المختصين.

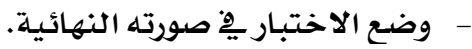

$$
\text { - - تطبيق التجريـة. }
$$

\section{تطبيـق التبمربـــة:}

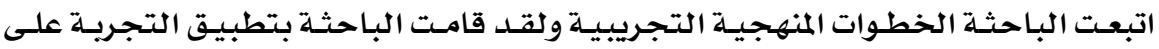

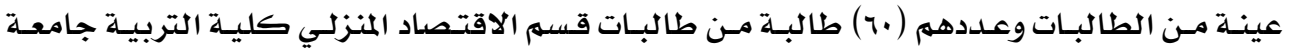

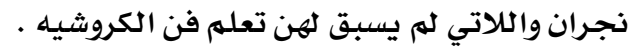

ا ـ التعرف على دور البرنامج المقترح يٍْ اكساب الطالبات للههارات الأساسية لفن الكروشيه .

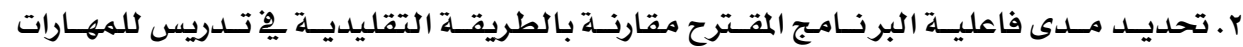

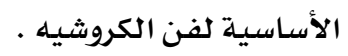

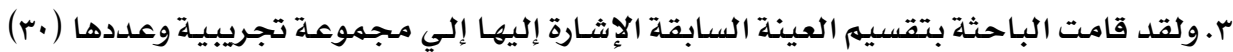

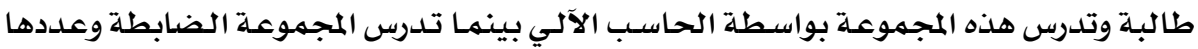

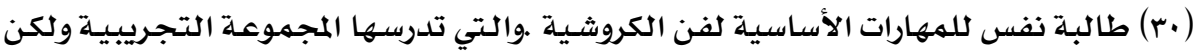

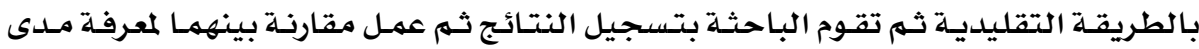

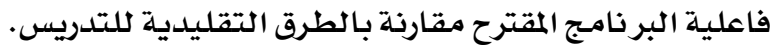




\section{إعداد هكان التجربة وأدواتها:}

اختارت الباحثة معمل الحاسب الآلي الموجود بالكلية حيث خصصت لكل طالبة من طالبـات

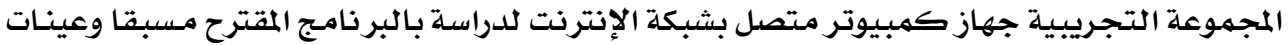
من الخيوط وإبر الكروشيه والمقصدات.

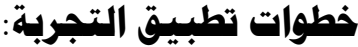

قامت الباحثة بالتطبيق مـع جميع أفراد العينة على شكل جلسـات خصصت لكل يوم مهارتان

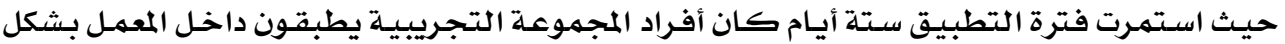

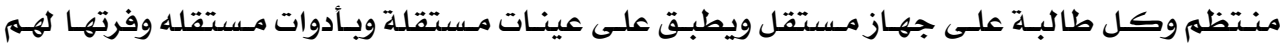
الباحثة.

كان أفراد المجموعة الضـابطة يطبقون لطريقـة التعليهم التقليديـة بواسطة الباحثة داخل

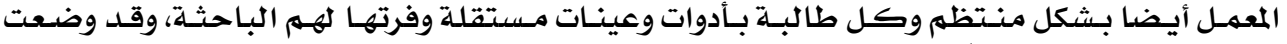

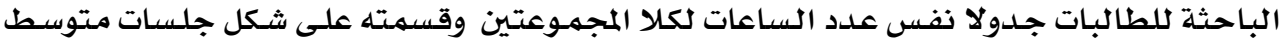

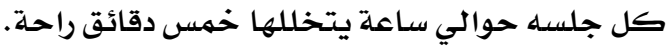

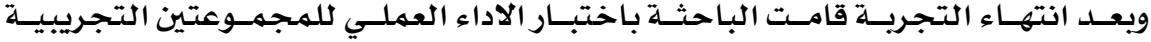

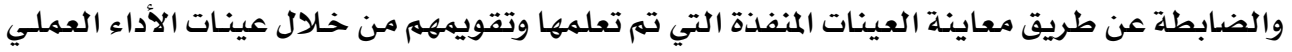

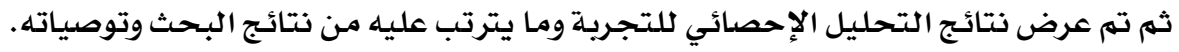
تحلديل محتوى البرنامج التعليمي المستخدم لتعليه المهارات الأساسية لفن الكروشيه:

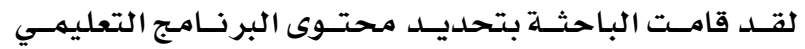

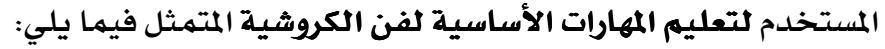

$$
\begin{aligned}
& \text { • مقدمـة عن فن الكروشية. } \\
& \text { • أنواع الإبر و مقاساتها } \\
& \text { • أنواع الخيوط و مقاساتها. } \\
& \text { • طريقة مسك الخيط . } \\
& \text { • طريقة مسك الإبرة } \\
& \text { • طريقة عقدة البدء لأي قطعة. }
\end{aligned}
$$

أهم غرز الكروشية البسيطة وأكثرها شيوعاً وهي:

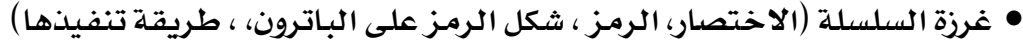

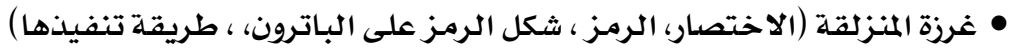

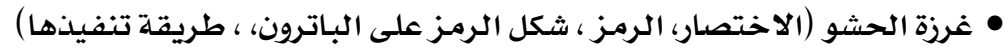

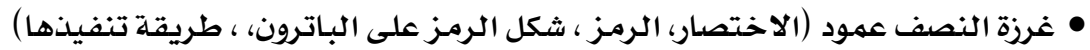


• غرزة العمود ( البريد ) (الاختصار، الرمزز ، شكل الرمز على الباترون، ، طريقة تنفيذها) أسس ومكونات البرنامج المقترح لتعليم المهارات الأساسية لفن الكروشيه:

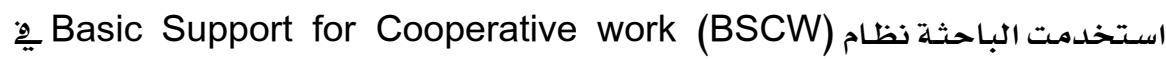

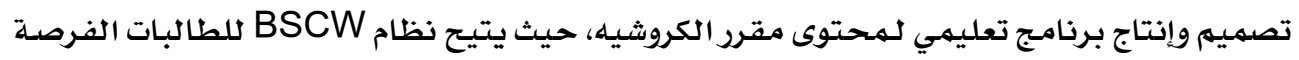

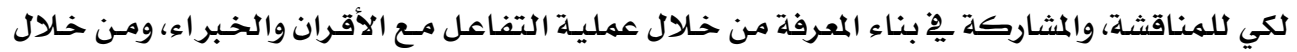

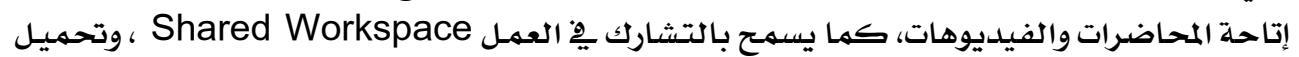

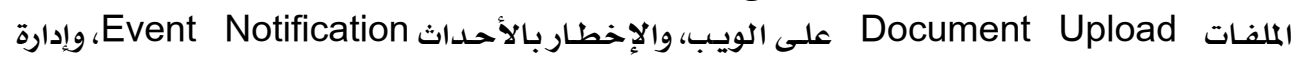

المجموعة Group Management

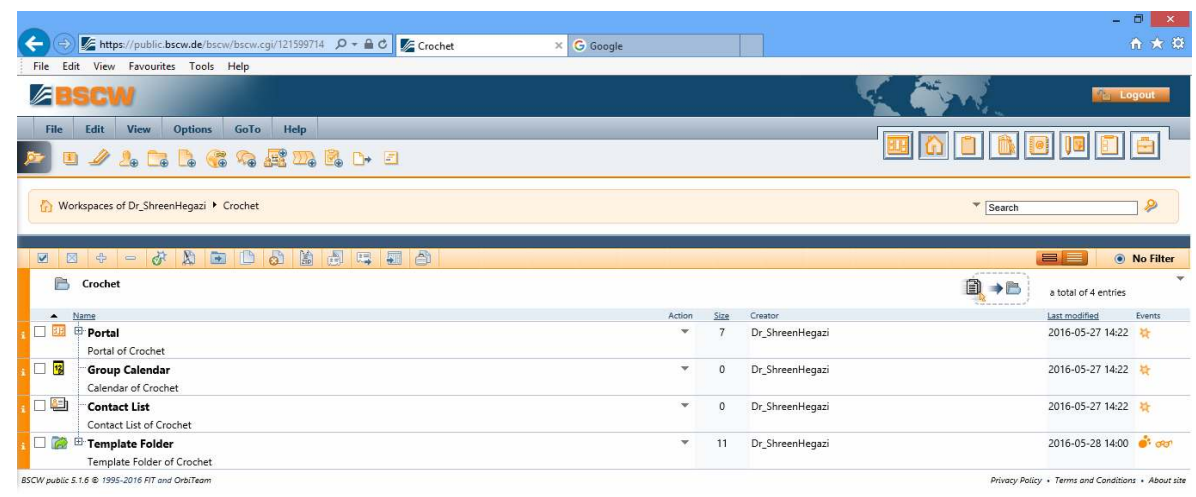

BSCW شكل (1) عناصر مقرد الكروشية على نظام

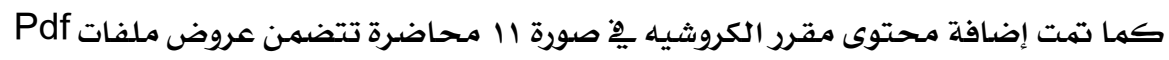

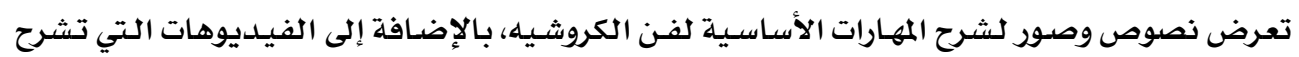

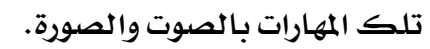

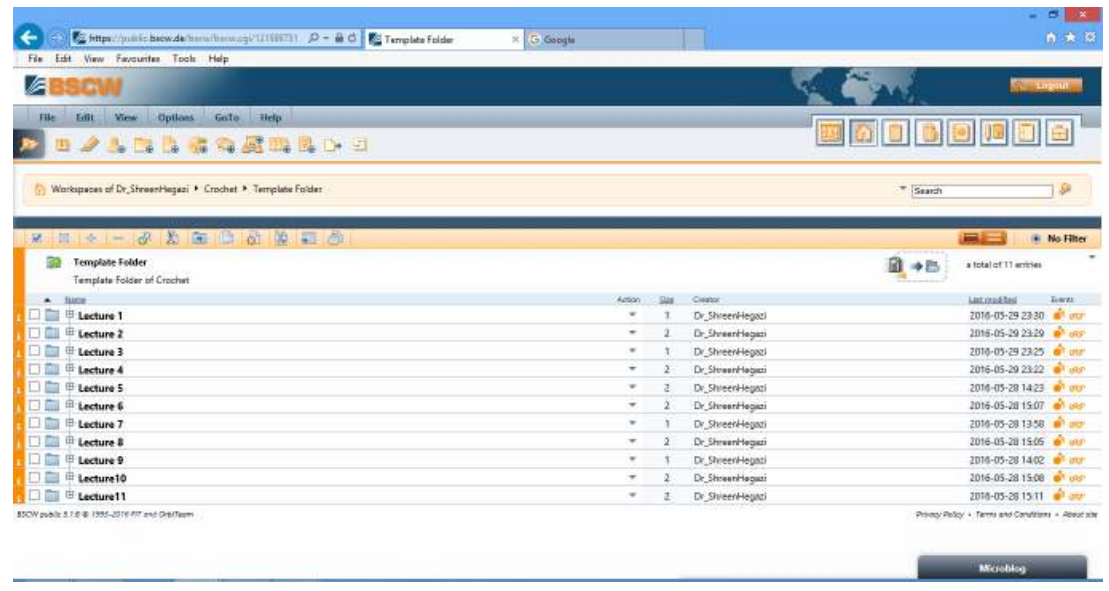

شكل (r) مجلدات محاضرات مقرر الكروشية على نظام BSCW 


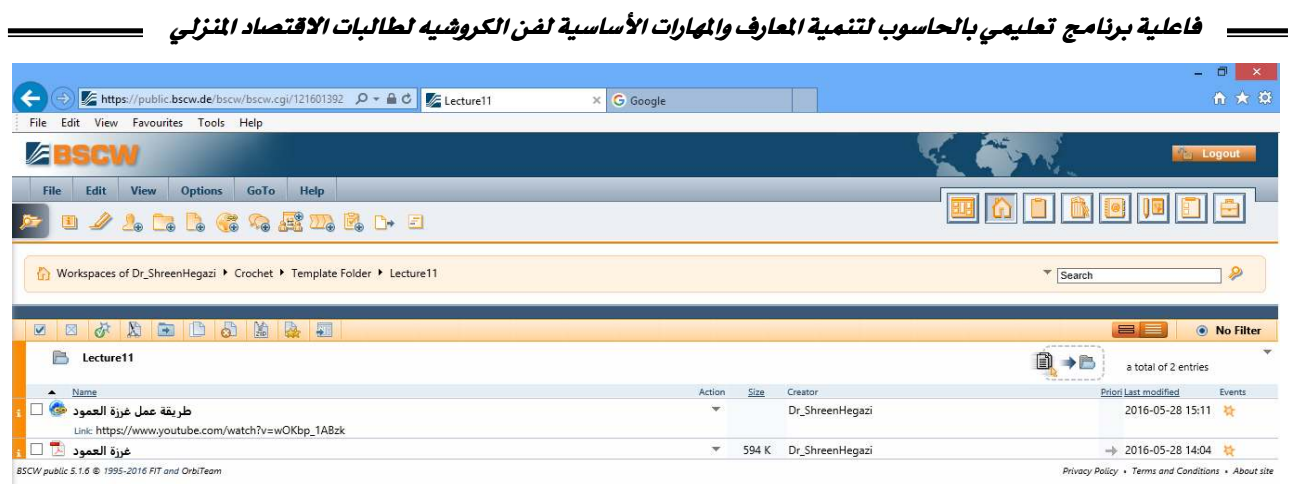

شكل (r) المحاضرة الحادية عشر التي تعرض طريقة عمل غرزة العمود وتتضمن فيديو وملف Pdf يعرض الشرح بالنه والهور

نتأُم البحث

ينص التسـاؤل الثاني من تسـاؤلات البـحث على:

مـا فاعليـة البرنامج المقـترح مقابل الطريقـة التقليديـة فِ تنميـة التحصيل الأكـاديعي

المرتبط بالمهارات الأساسية لفن الكروشيهء

للإجابـة على هـذا التسـاؤل، والـذي يهـدف إلى التعـرف على فاعليـة البرنـامـج المقترح مقابـل

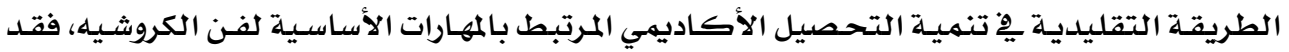
اتبعت الباحثة الخطوات التالية"

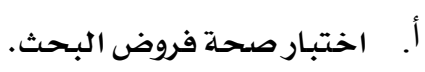

ب. تفسير النتائج ومناقشتها.

أـ اختبار صحة فروض البحث:

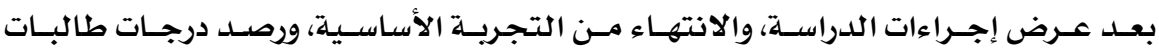

المجموعتين (التجريبية والضابطة) بالنسبة لاختبار التحصيل الأكاديهي المرتبط بالمهارات الأسـاسية

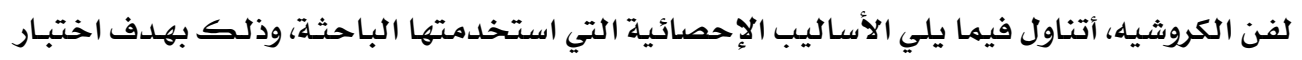
صححة الفروض:

بالنسبة للفرض الأول ونصه:

الفرض الأول:

توجد فروق ذات دلالة إحصائية عند مستوى (0. • • ) بين متوسطي درجـات طالبـات المجموعـة

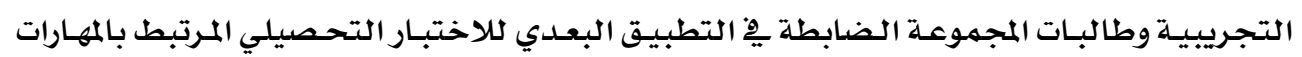
الأسـاسية لفن الكروشيـه لصالح المجموعة التجريبية. 


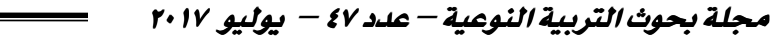

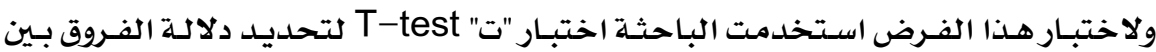

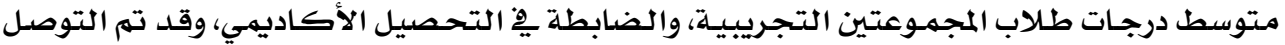

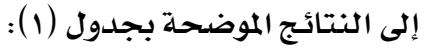

جدول (1) : دلالة "ت" للفرق بين متوسط درجات طالبات المجموعتين التجريبية، والضابطة 20

\begin{tabular}{|c|c|c|c|c|c|c|}
\hline مستوي الدلالة & قيمة ت & الفرق بين المتوسطين & الانحراف المعياري & المتوسط & العدد & المجموعة \\
\hline \multirow{2}{*}{ دال } & \multirow{2}{*}{$7, \xi Y r$} & \multirow{2}{*}{0, ro } & r,OlOYA & ro,o & re & التجريبية \\
\hline & & & r, \&Vrio & $r \cdot, r_{O}$ & r. & الضابطة \\
\hline
\end{tabular}

ومـن الجـدول السـابق يتضـح أن قيهـة "ت" للفـرق بـين متـوسطي درجـات طالبـات المجمـوعتين

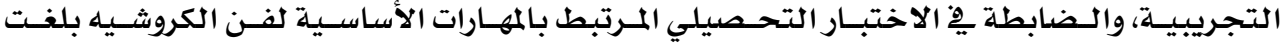

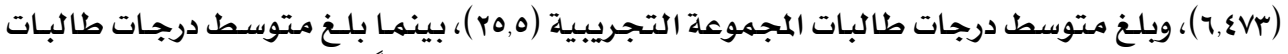

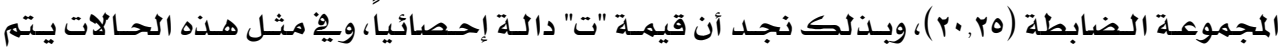

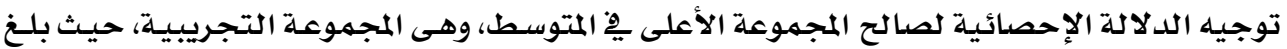
المتوسط الحسـابي لها (Y0,0) بهقدارزيادة عن المجموعة الضابطة يبلغ (0,0) .

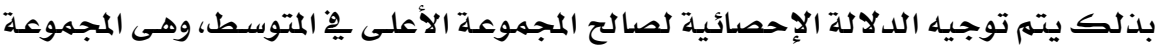
التجريبية (التي درست باستخدام البر نامج المقترح)، وعلى ذلك قبول الفرض الأول "توجـد فروق ذات

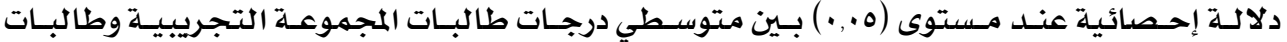

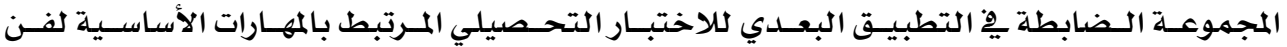
الكروشيه لصالح المجموعة التجريبيـة" . بـ تتفسير النتائج ومناقشتها:

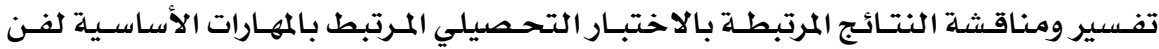
الكروشيـاه:

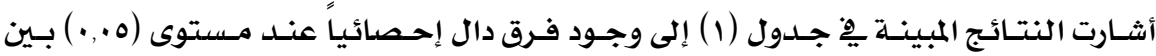

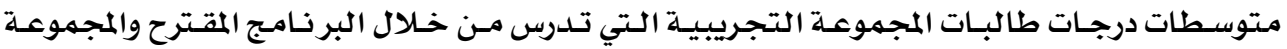
الضابطة التي تدرس بالطريقة التقليدية فِ التحصيل الأكاديهي لصالح المجموعة التجريبية، ويعد

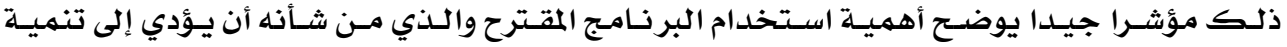

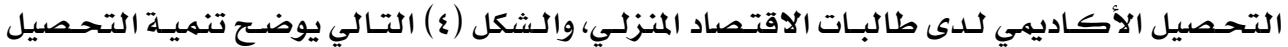

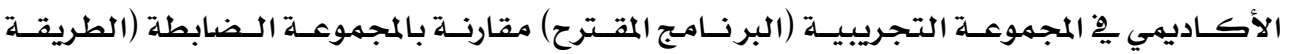




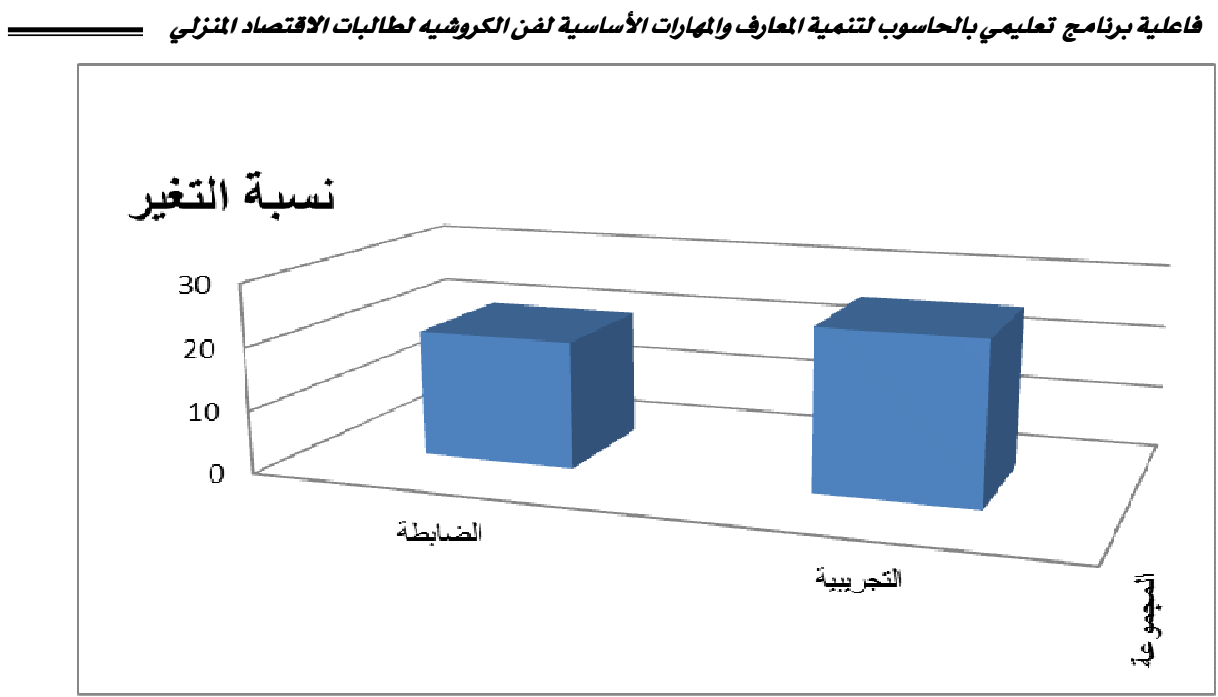

شكل رقم (ع) : المقارنة بين متوسطي درجات المجموعتين (التجريبية والضابطة)

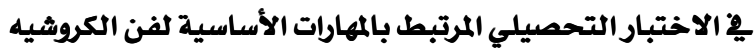
الإجابة عن التساؤل الثالث للبحث:

$$
\text { ينص التساؤل الثالث من تساؤلات البحث على: }
$$

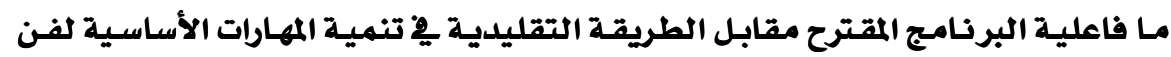
الكروشيهi

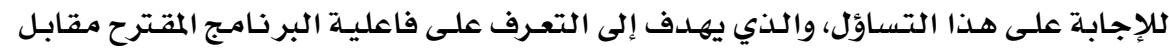

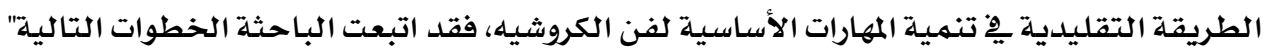

$$
\begin{aligned}
& \text { ج. اختبار صحهة فروض البحث. } \\
& \text { د. تفسير النتائج ومناقشتها. } \\
& \text { أـ اختبار صحة فروض البحث: }
\end{aligned}
$$

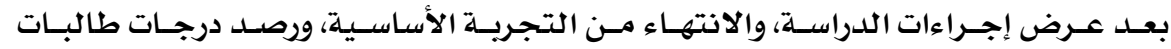

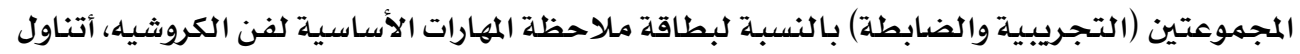

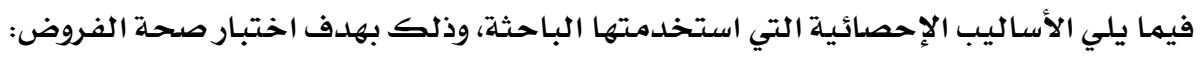
بالنسبة للفرض الثاني ونصه: الثرض الثاني:

توجد فروق ذات دلالة إحصائية عند مستوى (0., •) بين متوسطي درجـات طالبـات المجموعـة

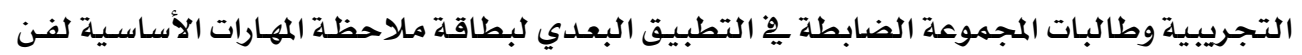

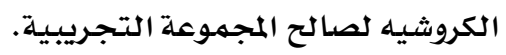




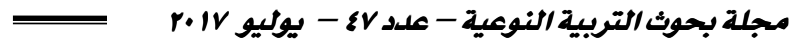

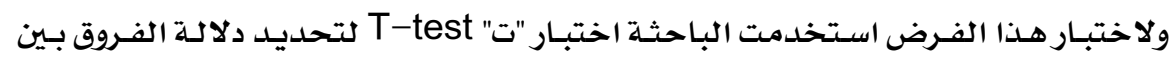

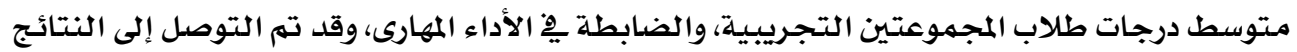

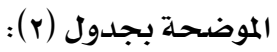

جدول (ץ) : دلالة "ت" للفرق بين متوسط درجات طالبات المجموعتين التجريبية، والضابطة يِ2

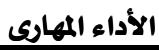

\begin{tabular}{|c|c|c|c|c|c|c|}
\hline مستوي الدلالة & قيمة ت & الفرق بين المتوسطين & |الانحراف المعياري & المتوسط & العدد & المجموعة \\
\hline \multirow{2}{*}{ دال } & \multirow{2}{*}{$V, 19 r$} & \multirow{2}{*}{$7, r r$} & r, yarry & rr, 77 & re & التجريبية \\
\hline & & & ร, rY\|q| & rv,rr & re & الضابطة \\
\hline
\end{tabular}

ومن الجـدول السـابق يتضـح أن قيمـة "ت" للفـرق بـين متوسطي درجـات طالبـات المجهـوعتين

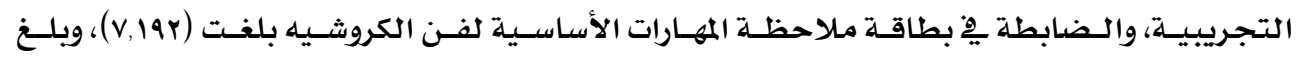

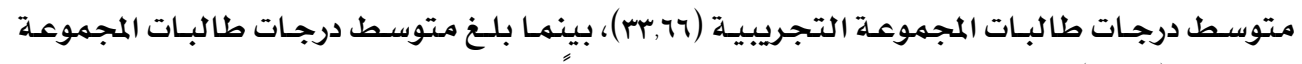

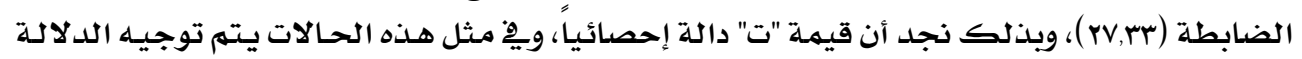

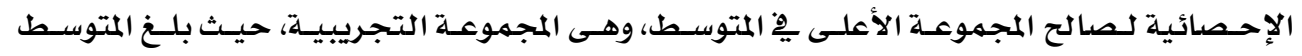

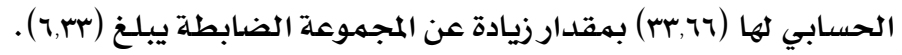

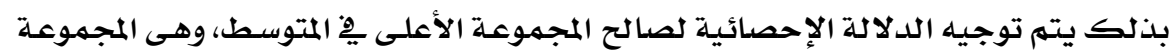

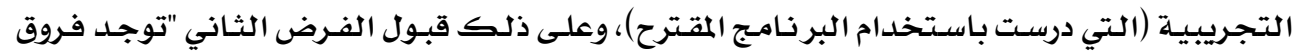

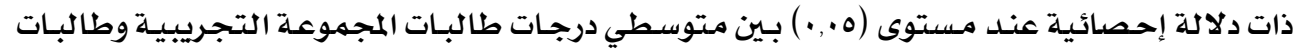

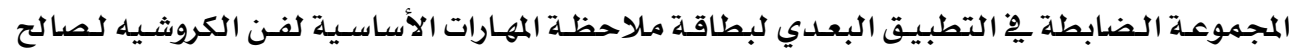
المجموعة التجريبية". بـ تقسير النتائج ومناقشتها: تفسير ومناقشة النتائج المرتبطة ببطاقة ملاحظة المهارات الأساسية لفن الكروشيه:

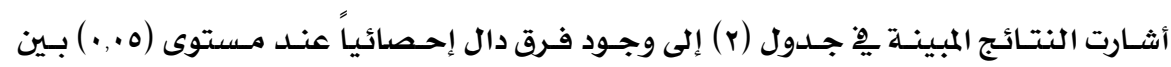

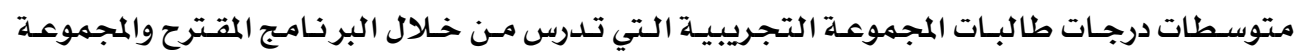

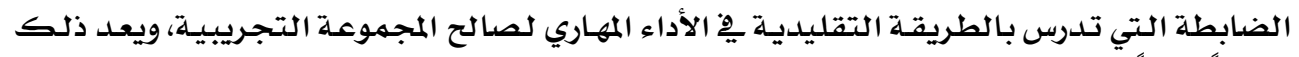

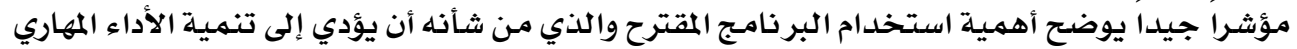

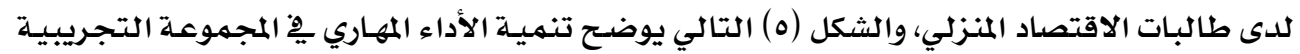

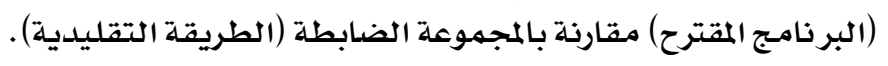




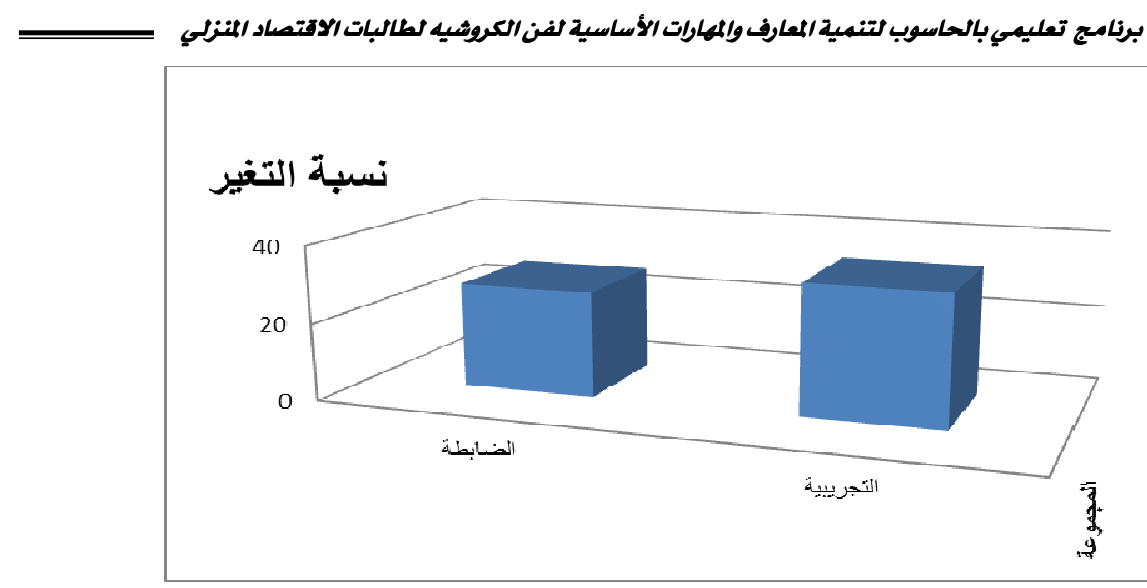

ثكل رقم (0) : المقارنة بين متوسطي درجات المجموعتين (التجريبية والضابطة)

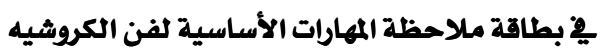

\section{التوصيات :}

يوصى البحثث بما يلى:

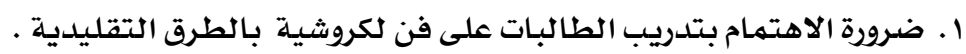

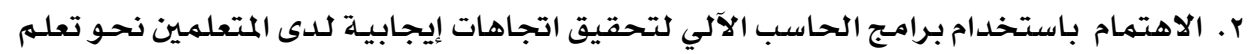

$$
\text { فن الكروشية . الامتهام باستخاح }
$$

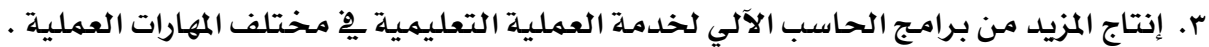

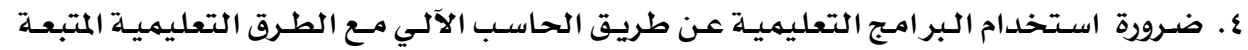

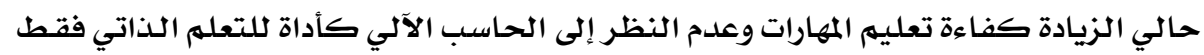

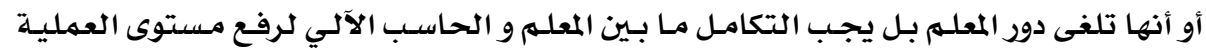

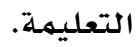

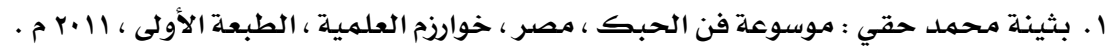

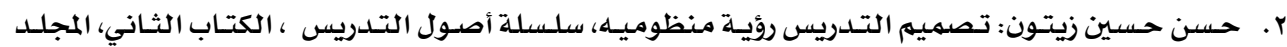

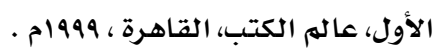

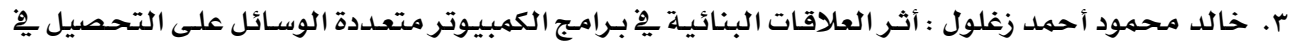

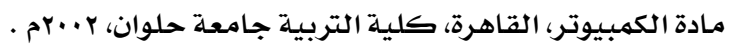

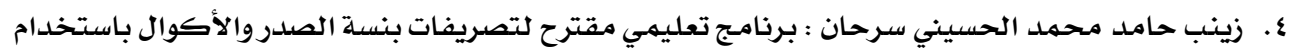

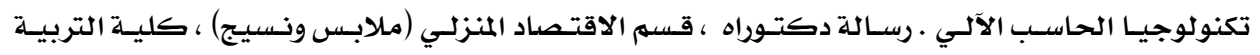

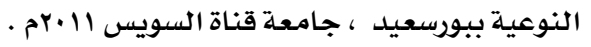


مجلة بحوث التربية النوعية - علد VV - يوليو V.lV

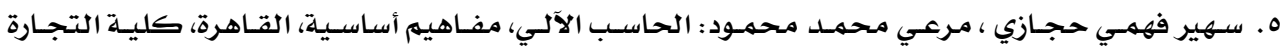

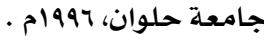

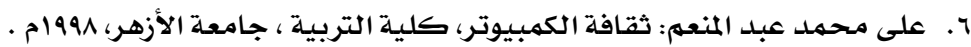

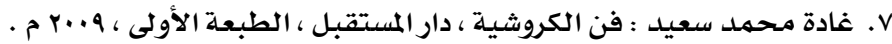

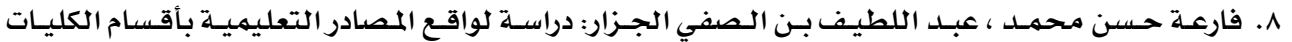

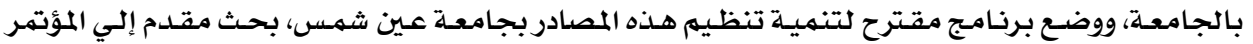

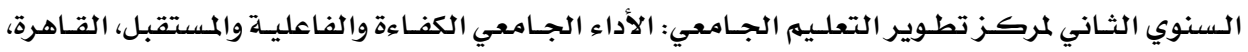

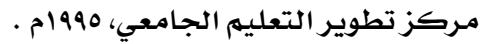

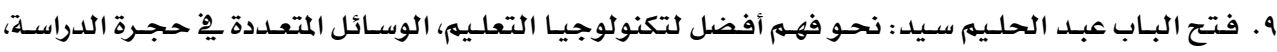
تكنولوجيا التعليم، دراسات وبحوث، 1990 م.

• ا. فتح الباب عبد الحليم سيد، على محمد عبد المنعمم وآخرين: برنامج تدريب المعلمين من بعد على استخدام

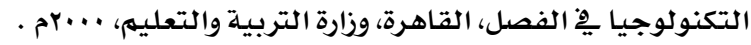

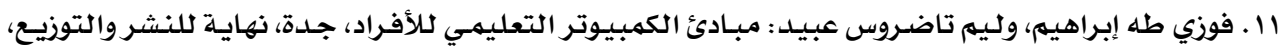
.1991

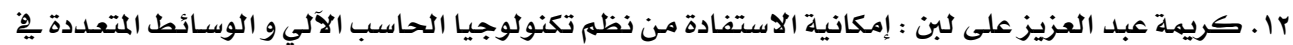
تدريس مادة الاقتصاد المنزلي لطلبة المرحلة الإعدادية ، رسالة ماجستير قسم الاقتصاد المنزلي ، ملابس و

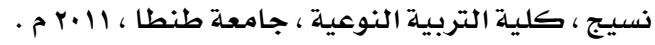

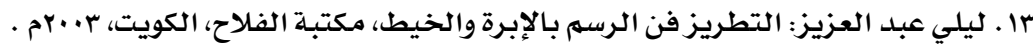

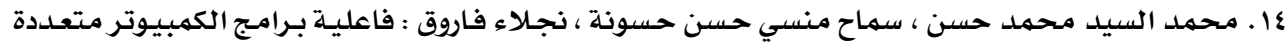

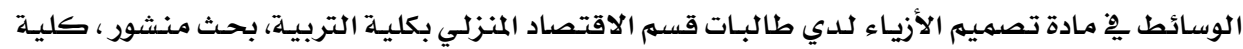

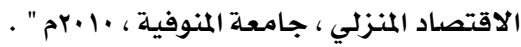

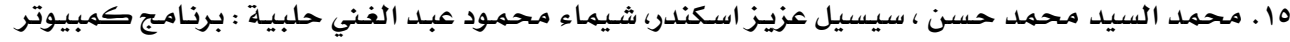

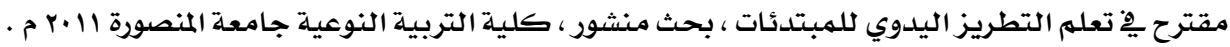

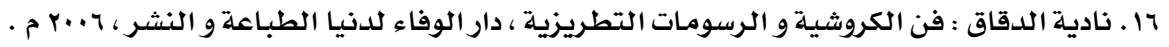

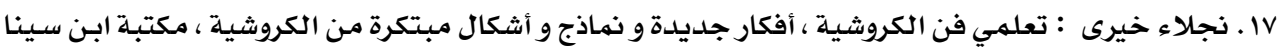
.

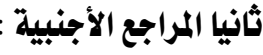

18.Acontantino- Gonzlez \& Suthers, D.D: Coaching participation, Dillenbour A. Elings, K. Hallarainen. European perspectives on computer oporter colhaborative learning proceedings of the first European ference on computer supported collaborative learning, the Netherlands, 2001.

19.Awton smith: Teaching as coaching, Helping students learn in ahnological world, Educause, 2002. 


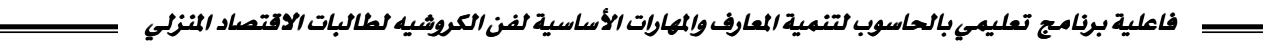

20.Barkar, John \& Ricahrd N Tuker. The interactive learning revelution, London, 1990.

21.Brian Bailey: Interactive sketching of multimedia storyboards. 1999.

22. Chalres E.L.: The Effect of three feed back methoolsin computer Addidted instruction on solving proportional problems, D.A, vol 47. 1986

23.Jeremy Galbreath: multimedia in education because it's there? Tech trends, vol 39, 1994.

24.Jennifer whyte: Virtual reality and built environment new york Architectural press, 2002.

25.J. mJ.m Durbin, The Benefits of combining computer technology and traditional teaching methods in large enrollment geo 26-26-26- science classes, journal of geoscience Education. Vol 50, 2002

26.Staples,N., R. pstger \&S. Davis, bod yscaming in the future, apparel Industry magazine, 55(101,48-55,1994).

27.Ak iyama, t., and others, computer pattern- making system by irpur of pashion drawing. V.automal pattersm

28.making by input of freehand fashion drawuing, journal of fextid machinery society of Japam, 47 (11), 59-67, 1994

29.Tolhurst , D. "hypertext, hypermedia , multimedia defind", Jowrnal of esucatianl techmology, vol 35, No.2, March- april.

30.Kanning, R.G (1994) what multimedia com do in our classrooms, Realizing the promise of texhmology, vol. 51, No.7, April.

31.Kim, S., tal Jen kang: de velopment of 2 D apparel cad system, the koveam fiber Society, spring conferece, 1997.

32.https://ar.wikipedia.org/wiki/\%D9\%83\%D8\%B1\%D9\%88\%D8\%B4\%D9\%8A $\% \mathrm{D} 9 \% 87$ 
مجلة بحوث التربية النوعية- عدد

The effectiveness of a computer education program to develop basic knowledge and skills of Crochaet art College of Education, Najran University

\section{Abstract}

Crochet art is important art for students of the Faculty of Education at the University of Najran and the existence of some of the lessons of the teacher that the teacher should teach the students with the free curriculum of the specialized courses that should have been taught by the graduate, Therefore, the researcher went on to prepare a proposed computer program to teach basic skills and knowledge of the art of Crochet. The researcher used Basic Support for Cooperative work (BSCW), The BSCW system provides students with the opportunity to discuss and engage in knowledgebuilding through interaction with peers and experts, The crocheted content was added in the form of 11 lectures, including presentations of PDF files showing texts and pictures to explain the basic skills of crochet art, as well as videos that explain these skills in audio and video

An achievement test was carried out to measure the performance of cognitive and remote knowledge and a note card to measure the skill performance during application in order to determine the effectiveness of the proposed program against the traditional method of developing academic achievement and developing the basic skills of the art of crochet 


\section{ב فاعلية برنامج تعليهي بالحاسوب لتنمية المعارف والمهارات الأساسية لفن الكموثيه لطالبات الوقتصاد المنزبي بـ الملاحق \\ همق رقم ( 1 )}

\section{جامعة نجران \\ كلية التربية \\ قسم الاقتصاد المنزئي}

تحية طيبة و بعد

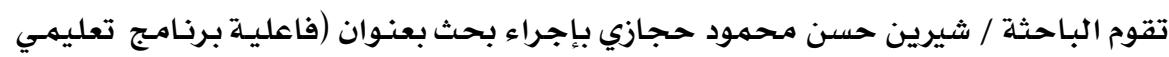

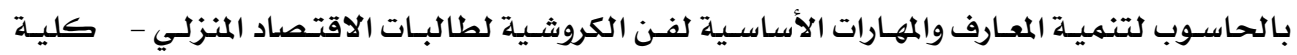

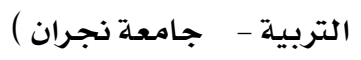

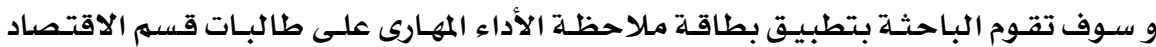

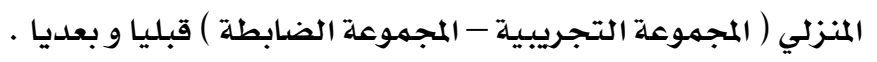

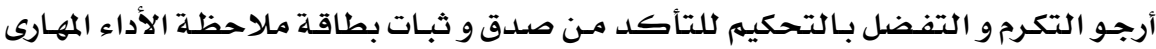

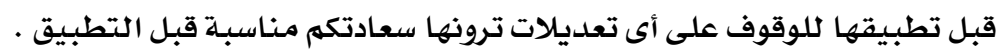

ولسعادتكم جزيل الشكر لتعاونكم

الباحثة

\begin{tabular}{|c|c|c|c|c|c|c|}
\hline \multicolumn{5}{|c|}{ مستوى الأداء } & \multirow[b]{2}{*}{ 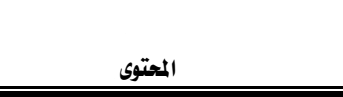 } & \multirow[t]{2}{*}{ P } \\
\hline ضعيف جدا & ضعيف & 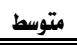 & 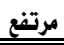 & مرتفع جلدا & & \\
\hline & & & & & تعدد الأدوات الخاصة بالكروشية & 1 \\
\hline & & & & & تختار الإبر ذات السن المناسب لنوع الخيط & $r$ \\
\hline & & & & & تصسك الإبرة أثناء العمل بطريقة سليمة & $r$ \\
\hline & & & & & تمسك الخيط أثناء العمل بطريقة صحيحة & $\varepsilon$ \\
\hline & & & & & تقوم بعمل عقدة البلداية & 0 \\
\hline & & & & & 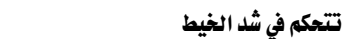 & 1 \\
\hline & & & & & تطبق عمل دائرة البداية & $r$ \\
\hline & & & & & تنفذ غرزة السلسلة & $\wedge$ \\
\hline & & & & & تعلد الغرز او السلاسل & 9 \\
\hline & & & & & تقطع الخيطو تنهى العمل & 1. \\
\hline & & & & & ترتفع عدد السلاسل المناسب لكل غرزة & 11 \\
\hline & & & & & تنفذ غرزة المنزلقة & ir \\
\hline & & & & & تنفذ غرزة الحشو & ir \\
\hline & & & & & تنفذ غرزة النصف عمود & $1 \xi$ \\
\hline & & & & & 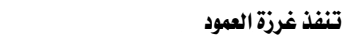 & 10 \\
\hline
\end{tabular}

بطاقة ملاحظة الأداء المهارى

\&. 


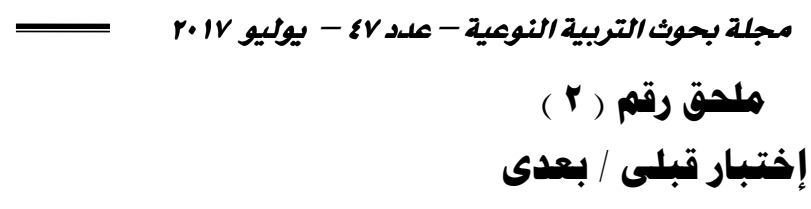

$$
\text { إختبار قبلى / بعدى رقى (r) }
$$

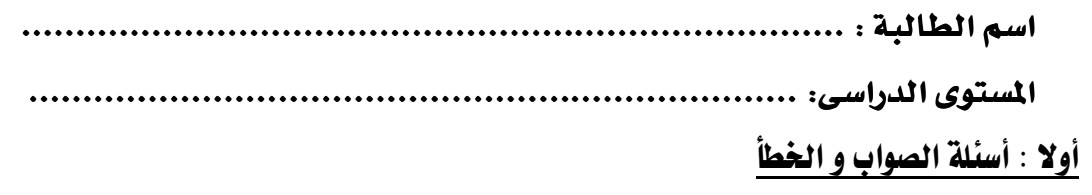

ضعي علامة (ل أمام العبارة الصحيحة وعلامة (×) أمام العبارة الخطأ:

أ- تعتبر غرزة السلسلة هى بـاية أى عمل فى الكروشية . . ب- من ادوات الكروشية الخيوط وإبرة الكروشية .

ج- يوجد طريقة واحدة فقط لمسك إبرة الكروشية . ل

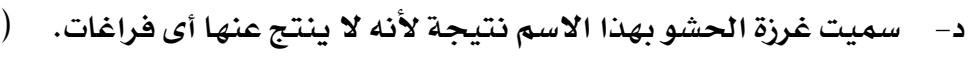

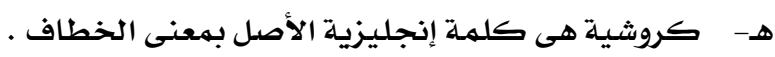

ثانيا أسئلة الاختيار من متعدد :

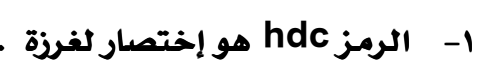

$$
\begin{aligned}
& \text { أ- الحشو . } \\
& \text { ب- السلسلة. } \\
& \text { ج- المنزلقة. } \\
& \text { د- النصف عمود }
\end{aligned}
$$

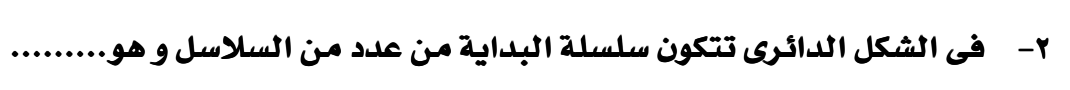

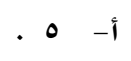

ب

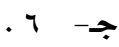

$9-2$

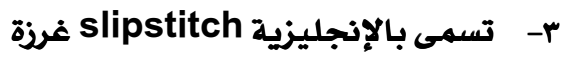

$$
\text { ب- ب- أ ب- السلسلة. }
$$




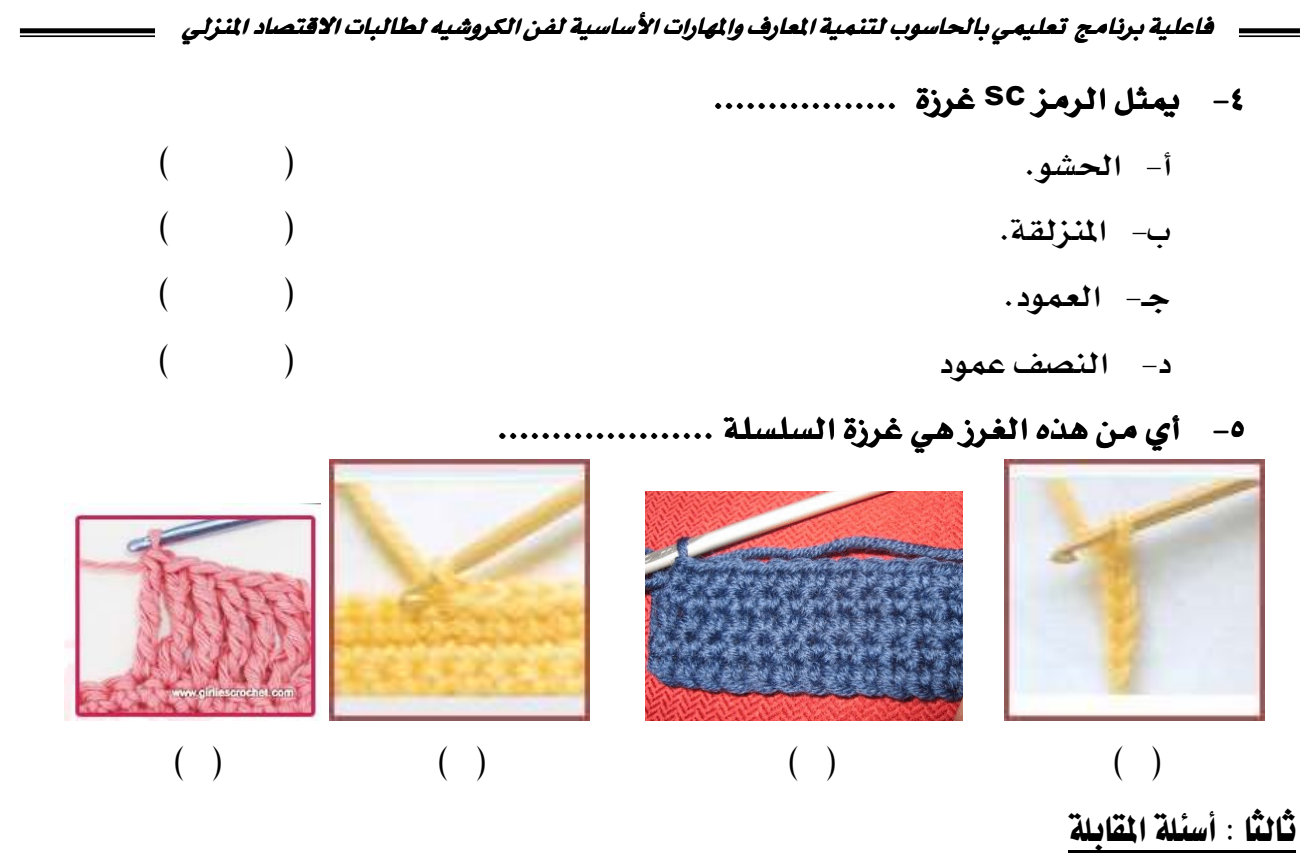

أمامك عمود ( أ ) يحتوى على أسماء بعض الفرز و فى العمود المقابل ( ب ) رموز هـذه الفرزعلى البـاتروز

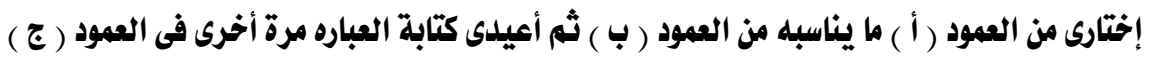

\begin{tabular}{|c|c|c|c|}
\hline ๕ & ب & i & A \\
\hline & & السلسلة & 1 \\
\hline & & المنزلقة & $r$ \\
\hline & & الحشو & $r$ \\
\hline & & نصف العمود & $\xi$ \\
\hline & & العمود & 0 \\
\hline
\end{tabular}

